\title{
DEVELOPMENT AND CHARACTERIZATION OF HIGHLY INFORMATIVE ELISA FOR THE DETECTION OF IgG AND IgA ANTIBODIES TO Chlamydia trachomatis
}

\author{
O. Yu. GALKIN ${ }^{1}$, Yu. V. GORSHUNOV', O. B. BESARAB', O. M. IVANOVA² \\ ${ }^{1}$ National Technical University of Ukraine "Igor Sikorsky Kyiv Polytechnic Institute”; \\ e-mail: alexfbt@gmail.com; \\ ${ }^{2}$ Xema Ltd., Kyiv
}

The goal of this work was developing of highly informative an enzyme-linked immunosorbent assay (ELISA) for the detection of IgG and IgA antibodies against to Chlamydia trachomatis, as well as comparative characterization of developed assay using standardized control materials. The study was conducted using: monoclonal antibodies (McAbs) to human IgA and IgG; recombinant Ch. trachomatis proteins - Pgp3, major outer membrane protein (MOMP); two panels of characterized sera and four reference ELISA kits. The study of immunochemical activity of peroxidase conjugates of McAbs was performed in comparison with conjugates of commercial analogues: anti-IgG McAb $2 A 11$ and anti-IgA McAb AD3. About half of the conjugates from the received McAbs panel were more active compared to the reference antibody conjugates. It was quite justified to use the conjugates of antibodies that interact with different antigenic determinants. When IgG antibodies were detected to MOMP, it was justified 1.14-1.56 times more; when IgA antibodies were detected to MOMP, it was justified 1.16-1.37 times more. ELISA for detecting IgG/IgA antibodies to MOMP and Pgp3 of Ch. trachomatis were evaluated using appropriately described serum panels OCO-42-28-313-00 and OCO-42-28314-00. Comparative studies of the developed ELISA for the detection of IgG and IgA antibodies to the MOMP and Pgp3 of Ch. trachomatis showed their prominent advantage over the commercial analogues, which more clearly demonstrates the difference in the ratio of average values of optical density of positive and negative samples of the described panel of sera: this indicator for commercial kits was 1.36-3.59 times less.

Ke y wo r d s: enzyme-linked immunosorbent assay, Chlamydia trachomatis, major outer membrane protein, Pgp3, sensitivity, specificity.

$\mathrm{U}$ rogenital chlamydia refers to one of the most common sexually transmitted infections. According to the World Health Organization, about 90 million people in the world every year become infected with the pathogen Chlamydia trachomatis [1]. In Ukraine, the incidence of urogenital chlamydia is 80 people per 100 thousand inhabitants. About $16 \%$ of pregnant women are infected with Ch. trachomatis [2]. The etiological role of Ch. trachomatis in 50-60\% of cases of tubal infertility has been established. One quarter of cases of ophthalmopathology and respiratory diseases in newborns and young children are associated with chlamydial infection [2].

One of the important components of the fight against the proliferation of urogenital chlamydia is the effective diagnosis of the disease, which is realized through direct (detection of antigens, nucleic acids, microscopy and cultivation of the pathogen), and indirect (detection of specific antibodies) methods. One of the methods that have been widely used in the diagnosis of urogenital chlamydia is an enzyme-linked immunosorbent assay (ELISA), the use of which allows for differential diagnosis - to determine the stage and nature of the course of the disease, which is especially important in the chronic course of the disease. For this purpose, the effect of human serum (plasma) and biological secrets on IgM, IgA, and IgG antibodies specific to Ch. trachomatis antigens is studied.

The major outer membrane protein (MOMP) plays the most important role for a serological diag- 
nostic purpose among all Ch. trachomatis antigens. This pathogen protein is considered the primary site for interaction with $\mathrm{T}$ cells, specific depending on serovar of microorganisms. MOMP is a transmembrane porin, parts of which are localized on the surface of the pathogen cell. Persistent Ch. trachomatis carry a smaller amount of MOMP involved in active transport. In MOMP absence, large hydrophilic molecules, including antibiotics do not penetrate inside chlamydia. MOMP is a highly specific protein for genital forms of chlamydial infections [2]. Other most immunogenic proteins of the pathogen include the plasmid protein Pgp3. With long Ch. trachomatis persistence increases the expression of $60 \mathrm{kDa}$ heat shock protein (HSP-60), which has a high degree of homology with a human protein of a similar size. HSP-60 production leads to the phenomenon of molecular mimicry, which in turn often causes autoimmune processes [3, 4].

Serologic methods of diagnosis of chlamydial infection can determine the stage and nature of the course of the disease, which is especially important in the chronic course of the disease for many months and years. For this purpose, in the ELISA, specific antibodies of the IgM, IgA, and IgG classes are gradually synthesized and accumulated in the blood serum and in the biological secrets of humans. Specific IgA-class antibodies are present in both serum and secretory forms; they are indicators of both acute infection and manifestation in a chronic form of the disease. In serum, antibodies of the IgA class appear 10-14 days after the onset of the disease, a little earlier than the antibodies of the IgG class, but at lower concentrations. They can be detected at the onset of the disease in the secretions of the genital organs. High concentrations of antibodies in this class may indicate a chronic infection. Specific IgA antibodies have a half-life of 5-7 days, which allows them to be used to control the treatment effectiveness. Reducing the level of these antibodies 2-3 times indicates successful therapy. IgG antibodies appear from the third week after the onset of the disease. Their presence reflects the general picture of the immune response as a result of acute, chronic or transmitted infection. In the latter case, IgG can be found to be low for many years $[5,6]$.

Thus, the development of modern highly informative test-kits for serological diagnostics of urogenital chlamydia is an important task for health protection.
The aim of the work was developing of highly informative ELISA for the detection of IgG and IgA antibodies against to Ch. trachomatis using highly active and specific biological and chemical reagents, as well as comparative characterization of developed assay using standardized control materials.

\section{Materials and Methods}

Monoclonal antibodies (McAbs) to human IgA and IgG have been obtained and described earlier [7]. All antibodies of these panels were characterized by high activity in the indirect ELISA (to the corresponding immunoglobulin and its Fc fragments), high titre in the culture fluid and the affinity constant (Table 1 and Table 2).

Recombinant proteins (antigens). Two recombinant $C h$. trachomatis proteins were used to construct ELISA test-kits: Pgp3, MOMP (Virogen, USA).

Periodate method of synthesis of peroxidase antibody conjugates. Conjugation of McAbs with horseradish peroxidase (HRP) (alkaline form) (Sigma, USA) was carried out at the mass ratio antibodies : enzymes equal $2: 1$ by the method of periodate oxidation by Tissen [8] with own modifications [9]. HRP was dissolved in $0.1 \mathrm{M}$ carbonatebicarbonate buffer solution (CBBS), $\mathrm{pH}$ 8.0, up to a concentration of $15 \mathrm{mg} / \mathrm{ml}$, and then equal volume of water solution of sodium periodate $(14 \mathrm{mM})$ was added. For HRP oxidation reaction mixture was incubated for $2 \mathrm{~h}$ at room temperature. The obtained solution of oxidized HRP was mixed with a solution of dialyzed antibodies (against 0.1 M CBBS, $\mathrm{pH}$ 9.2). The mixture was cyclically passed through a $0.45 \mu \mathrm{m}$ filter for $10 \mathrm{~min}$ at room temperature (filter material was a mixture of biologically inert acetate and cellulose nitrate, Millipore, USA). The conjugate solution was eluted from the column and a 1/20 volume portion of aqueous $\mathrm{NaBH}_{4}$ solution $(5 \mathrm{mg} /$ $\mathrm{ml}$ ) was added. To stop the reaction, the mixture was cooled to $4{ }^{\circ} \mathrm{C}$, and then another $3 / 20$ part of $\mathrm{NaBH}_{4}$ solution was added, incubated for $60 \mathrm{~min}$ at room temperature. The resulting solution of peroxidase conjugate McAbs was transferred to $0.02 \mathrm{M}$ phosphate buffer solution containing $0.15 \mathrm{M} \mathrm{NaCl}$ (PBS), $\mathrm{pH}$ 7.2, by dialysis.

The panels of characterized serums. For the primary characteristics of the McAbs conjugates the intra-laboratory serum panels (ILPs) were used, which were based on the results of testing the serum samples of people with a confirmed diagnosis of uro- 
Ta ble 1. The complex characteristic of monoclonal antibodies to the human IgA Fc fragment

\begin{tabular}{l|cc|c|c|c|c}
\hline \multirow{2}{*}{ McAbs } & \multicolumn{2}{|c|}{ Optical density in ELISA ${ }^{1)}$} & \multirow{2}{*}{ Isotype } & $\begin{array}{c}\text { Titre in culture } \\
\text { fluid }{ }^{1)}\end{array}$ & $\begin{array}{c}\text { Affinity constant }{ }^{1)} \text {, } \\
10^{9} \mathrm{M}^{-1}\end{array}$ & Epitope $^{2)}$ \\
\cline { 2 - 3 } 131A9 & 2.235 & 2.022 & $\operatorname{IgG}_{2 \mathrm{~b}}$ & $1: 500$ & 12.0 & $\mathrm{~A} 2.1$ \\
131D11 & 2.201 & 1.899 & $\operatorname{IgG}_{2 \mathrm{~b}}$ & $1: 1000$ & 2.5 & $\mathrm{~A} 2.2$ \\
132B6 & 1.780 & 1.802 & $\operatorname{IgG}_{2 \mathrm{~b}}$ & $1: 500$ & 2.5 & $\mathrm{~A} 2.2$ \\
132F12 & 1.998 & 2.010 & $\operatorname{IgG}_{2 \mathrm{~b}}$ & $1: 1000$ & 12.0 & $\mathrm{~A} 2.1$ \\
133E9 & 2.685 & 2.667 & $\operatorname{IgG}_{2 \mathrm{a}}$ & $1: 1000$ & 5.0 & $\mathrm{~A} 2.2$ \\
133G12 & 1.423 & 1.586 & $\operatorname{IgG}_{1}$ & $1: 1000$ & 10.0 & $\mathrm{~A} 2.3$ \\
134C9 & 2.632 & 2.662 & $\operatorname{IgG}_{2 \mathrm{~b}}$ & $1: 500$ & 14.0 & $\mathrm{~A} 2.1$ \\
136A9 & 2.562 & 2.441 & $\operatorname{IgG}_{2 \mathrm{~b}}$ & $1: 800$ & 10.0 & $\mathrm{~A} 2.3$ \\
136D5 & 2.321 & 2.322 & $\operatorname{IgG}_{2 \mathrm{~b}}$ & $1: 1000$ & 11.0 & $\mathrm{~A} 2.3$ \\
136D6 & 2.952 & 2.801 & $\operatorname{IgG}_{2 \mathrm{~b}}$ & $1: 500$ & 8.0 & $\mathrm{~A} 2.3$ \\
136E12 & 3.031 & 2.885 & $\operatorname{IgG}_{2 \mathrm{~b}}$ & $1: 500$ & 5.0 & $\mathrm{~A} 2.3$ \\
137C10 & 1.920 & 1.881 & $\operatorname{IgG}_{1}$ & $1: 500$ & 5.0 & $\mathrm{~A} 2.2$ \\
137D5 & 2.325 & 2.380 & $\operatorname{IgG}_{2 \mathrm{~b}}$ & $1: 800$ & 10.0 & $\mathrm{~A} 2.3$ \\
142C5 & 3.032 & 2.984 & $\operatorname{IgG}_{1}$ & $1: 500$ & 1.0 & $\mathrm{~A} 1.2$ \\
143D4 & 3.051 & 2.988 & $\operatorname{IgG}_{1}$ & $1: 1000$ & 8.0 & $\mathrm{~A} 1.1$ \\
144D11 & 3.023 & 2.988 & $\operatorname{IgG}_{3}$ & $1: 1000$ & 5.0 & $\mathrm{~A} 1.1$ \\
146B1 & 3.165 & 2.998 & $\operatorname{IgG}_{2 \mathrm{a}}$ & $1: 2000$ & 1.0 & $\mathrm{~A} 1.2$ \\
146H9 & 2.878 & 2.877 & $\operatorname{IgG}_{1}$ & $1: 400$ & 2.0 & $\mathrm{~A} 1.2$ \\
\hline
\end{tabular}

Note. ${ }^{1)}$ The average values according to the results of the testing in 4 repetitions are given $(P<0.05) .{ }^{2)}$ Symbol of epitope and epitopic region based on comparative epitope mapping.

Ta ble 2. The complex characteristic of monoclonal antibodies to the human IgG Fc fragment

\begin{tabular}{|c|c|c|c|c|c|c|}
\hline \multirow{2}{*}{ McAbs } & \multicolumn{2}{|c|}{ Optical density in ELISA ${ }^{1)}$} & \multirow{2}{*}{ Isotype } & \multirow{2}{*}{$\begin{array}{l}\text { Titre in culture } \\
\quad \text { fluid }{ }^{1)}\end{array}$} & \multirow{2}{*}{$\begin{array}{l}\text { Affinity constant } \\
\qquad 10^{9} \mathrm{M}^{-1}\end{array}$} & \multirow{2}{*}{ Epitope $^{2}$} \\
\hline & IgG & IgG Fc fragment & & & & \\
\hline 201C8 & 3.001 & 2.985 & $\operatorname{IgG}_{1}$ & $1: 800$ & 20.0 & G1.2 \\
\hline 201F10 & 2.889 & 2.661 & $\operatorname{IgG}_{1}$ & $1: 800$ & 10.0 & G2 \\
\hline 202B7 & 3.094 & 3.002 & $\operatorname{IgG}_{2 \mathrm{a}}$ & $1: 1000$ & 20.0 & G1.1 \\
\hline 202D10 & 3.112 & 3.066 & $\operatorname{IgG}_{2 \mathrm{a}}$ & $1: 1000$ & 28.0 & G1.1 \\
\hline 203D10 & 2.145 & 2.321 & $\operatorname{IgG}_{1}$ & $1: 800$ & 20.0 & G1.2 \\
\hline 203G4 & 2.333 & 2.451 & $\operatorname{IgG}_{2 \mathrm{~b}}$ & $1: 800$ & 16.0 & G2 \\
\hline 206B2 & 3.008 & 2.988 & $\operatorname{IgG}_{1}$ & $1: 800$ & 20.0 & G1.1 \\
\hline 206C8 & 3.015 & 3.025 & $\operatorname{IgG}_{2 b}$ & $1: 1000$ & 28.0 & G1.2 \\
\hline $206 C 12$ & 2.455 & 2.399 & $\operatorname{IgG}_{1}$ & $1: 500$ & 8.0 & G2 \\
\hline 206E3 & 3.071 & 3.001 & $\operatorname{IgG}_{2 \mathrm{a}}$ & $1: 500$ & 8.0 & G1.2 \\
\hline 206H11 & 2.544 & 2.651 & $\operatorname{IgG}_{1}$ & $1: 800$ & 8.0 & G2 \\
\hline 207F3 & 2.918 & 2.899 & $\operatorname{IgG}_{2 b}$ & $1: 800$ & 20.0 & G1.2 \\
\hline
\end{tabular}

Note. ${ }^{1)}$ The average values according to the results of the testing in 4 repetitions are given $(P<0.05) .{ }^{2)}$ Symbol of epitope and epitopic region based on comparative epitope mapping. 
genital chlamydiosis (including PCR tests), as well as healthy donors. The formation of ILPs was carried out by testing of serum samples in commercial ELISA kits for detection of IgG or IgA antibodies to Ch. trachomatis MOMP. For final evaluation of sensitivity and specificity of the developed ELISA the commercial characterized serum panels OCO42-28-313-00 and OCO-42-28-314-00 containing and not containing $\mathrm{IgG} / \mathrm{IgA}$ specific antibodies to Ch. trachomatis (Medical Biological Union, Russia) were used.

Diagnostic characteristics of ELISA and immunoenzyme conjugates. To assess the diagnostic quality of immunoenzyme conjugates and the analysis as a whole, the positivity index (PI) was used. PI was calculated as the ratio of the average value of the positive samples optical density to the cut-off value. In turn, the cut-off value was calculated as the sum of the average value of the negative samples optical density and the threefold value of the standard deviation. To evaluate the analysis, the ratio between the mean values of optical density of positive and negative samples was also used.

Statistical methods. Statistical processing of the results was performed using Student's t-criterion. In order to assess the acceptability of the number of repeated measurements the experimental level of significance of $P$ was used in the calculation of the PI. It was considered sufficient if the calculated value of the criterion calculated by the sample did not exceed the critical value of the significance level $\alpha=0.05$ $(P<0.05)$.

Bioethical norms. The research was conducted in accordance with international and national bioethical recommendations.

\section{Results and Discussion}

Rationale of ELISA configuration. It is known that the main serological markers of urogenital chlamydia are IgG and IgA class antibodies specific to Ch. trachomatis. The literature describes various antigenic proteins of the pathogen, including cell wall proteins; however, the most immunogenic is the major outer membrane protein, the plasmid protein Pgp3, as well as HSP-60 and HSP-70 are the most immunogenic ones [10-14]. Manufacturers of commercial diagnostic kits usually use only one type of antigen to detect antibodies by certain test-kit [15-17]. In our opinion, such an approach is not rational, since it reduces the diagnostic informativeness of the ELISA a priori. Therefore, it is advisable to use a combina- tion of different antigens of the pathogen in the development of diagnostic test-kits. It is obvious that the combination of antigens should be grounded in the pathogenesis of the disease. Thus, for example, it is inappropriate to construct ELISA for simultaneous detection of antibodies to the MOMP and heat shock proteins, since these serological markers, each separately, allow for differential diagnosis and/or control of therapeutic efficacy. Instead, in order to establish the initial diagnosis (screening), it is expedient to codetect antibodies to the MOMP and Pgp3. A similar approach is implemented, for example, in serological diagnosis of hepatitis $C$ and syphilis [18, 19].

Based on the foregoing, the task was to develop an immunoassay for the detection of IgG and IgA antibodies to two antigens of the pathogen (MOMP and Pgp3). For development, a basic variant of the indirect ELISA was used, which provided for the presence of a number of biological components with certain properties, namely: recombinant proteins MOMP, Pgp3 and HSP-60, as well as conjugates of monoclonal antibodies to human IgG and IgA. Development of ELISA for detection of IgG antibodies specific to Ch. trachomatis heat shock protein (HSP60) was described by us before [20], that is why we will not dwell on this issue at this time.

Immunochemical characterization of peroxidase conjugates of McAbs specific to human $\operatorname{IgG}$ and IgA, and the development of ELISA test-kit. In order to realize the task at the first stage, it was necessary to synthesize peroxidase conjugates of the anti-species monoclonal antibodies (anti-IgG, anti-IgA). To obtain conjugates we used the most suitable method in this case, the personal method (with own modifications). The synthesized peroxidase conjugates were characterized in ELISA to detect appropriate antibodies specific to the antigen of the pathogen of urogenital chlamydiosis using an evaluation panel of sera (internally laboratorial sera panel). Conjugates of anti-IgG and anti-IgA antibodies were characterized by ELISA to detect appropriate antibodies to the MOMP. This characteristic of the conjugates of self obtained McAbs was performed in comparison with conjugates of McAbs of the same specifics obtained by other authors: anti-IgG McAb 2A11 and anti-IgA McAb AD3 (Sorbent, Russia) (Fig. 1-2). The best McAbs' conjugates were also tested in ELISA for detection of anti-IgG and anti-IgA antibodies to the pathogen protein Pgp3 (Fig. 3-4).

The obtained results indicate that most of the conjugates of self obtained McAbs are above their respective commercial counterparts by its activity. 


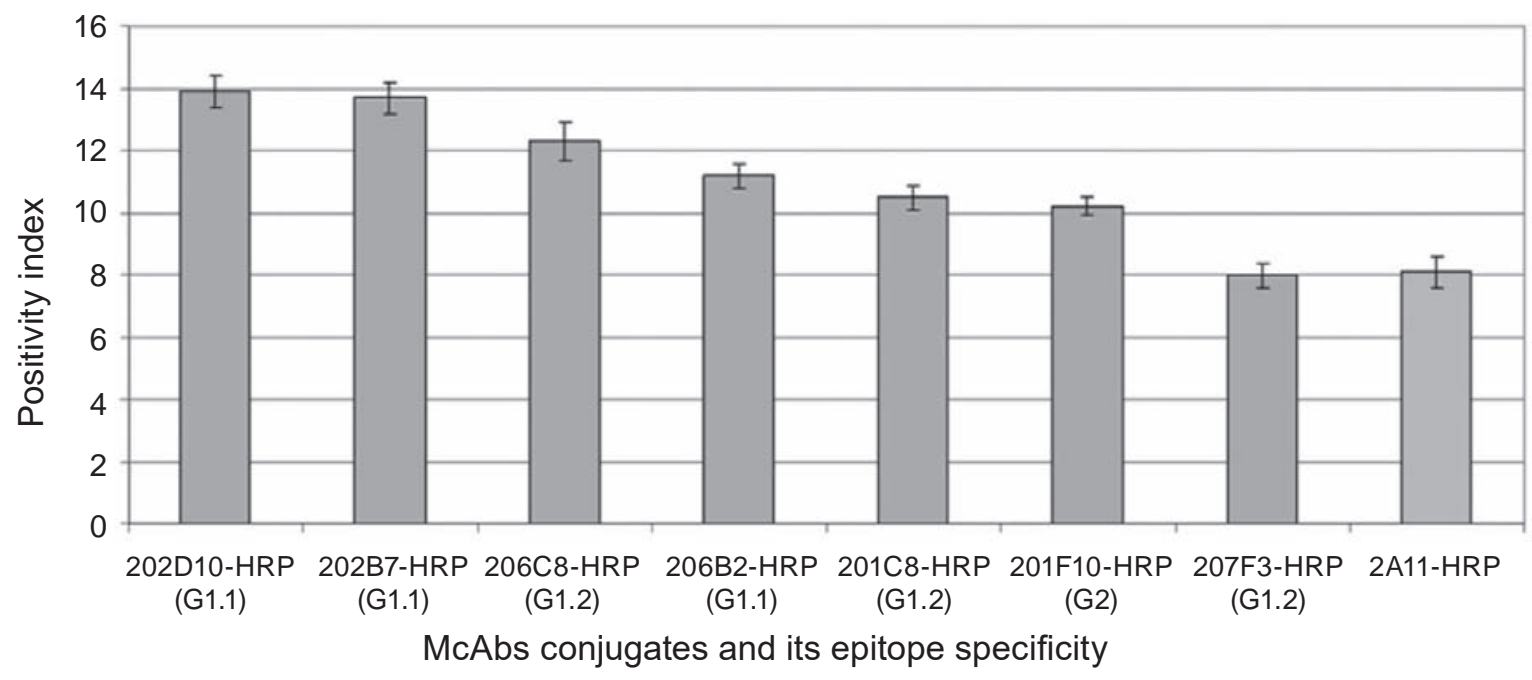

Fig. 1. Results of the primary characterization of McAbs to human IgG in the ELISA to detect IgG antibodies to MOMP (PI calculation was based on the results of three replies testing of 8 negative and 8 positive sera for specific anti-MOMP IgG antibodies; $P<0.05$ )

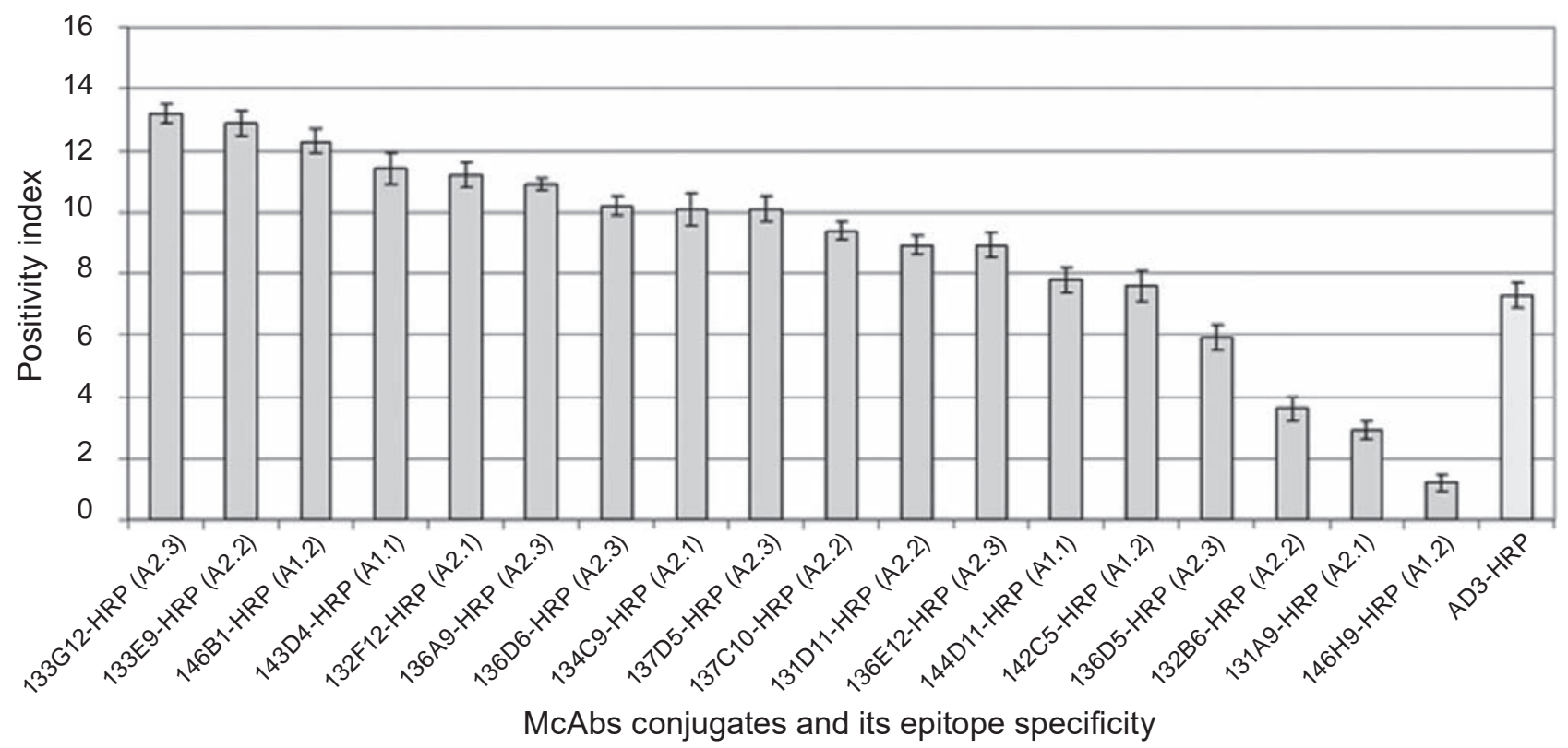

Fig. 2. Results of the primary characterization of McAbs to human IgA in the ELISA to detect IgA antibodies to MOMP (PI calculation was based on the results of three replies testing of 8 negative and 8 positive sera for specific anti-MOMP IgA antibodies; $P<0.05)$

Subsequent studies were aimed at studying the possibility of the joint use of peroxidase conjugates of self obtained McAbs. The prerequisites for these studies were the results of relative epitope mapping of the McAbs (Table 1-2).

Given that obtained McAbs were directed to different epitopic regions and different epitopes within a single epitopic region, it is likely from the theoretical point of view that signal strength en- hancement in the ELISA is quite possible with the consistent use of non-competing McAbs conjugates (or such a competition is minimal).

Analyzing the results of the primary characteristics in the ELISA of the conjugates of McAbs to human IgG (Fig. 1) and the immunochemical properties of anti-IgG McAbs (Table 2), we selected two pairs of McAbs, which in our opinion may be promising for design highly sensitive ELISA test- 


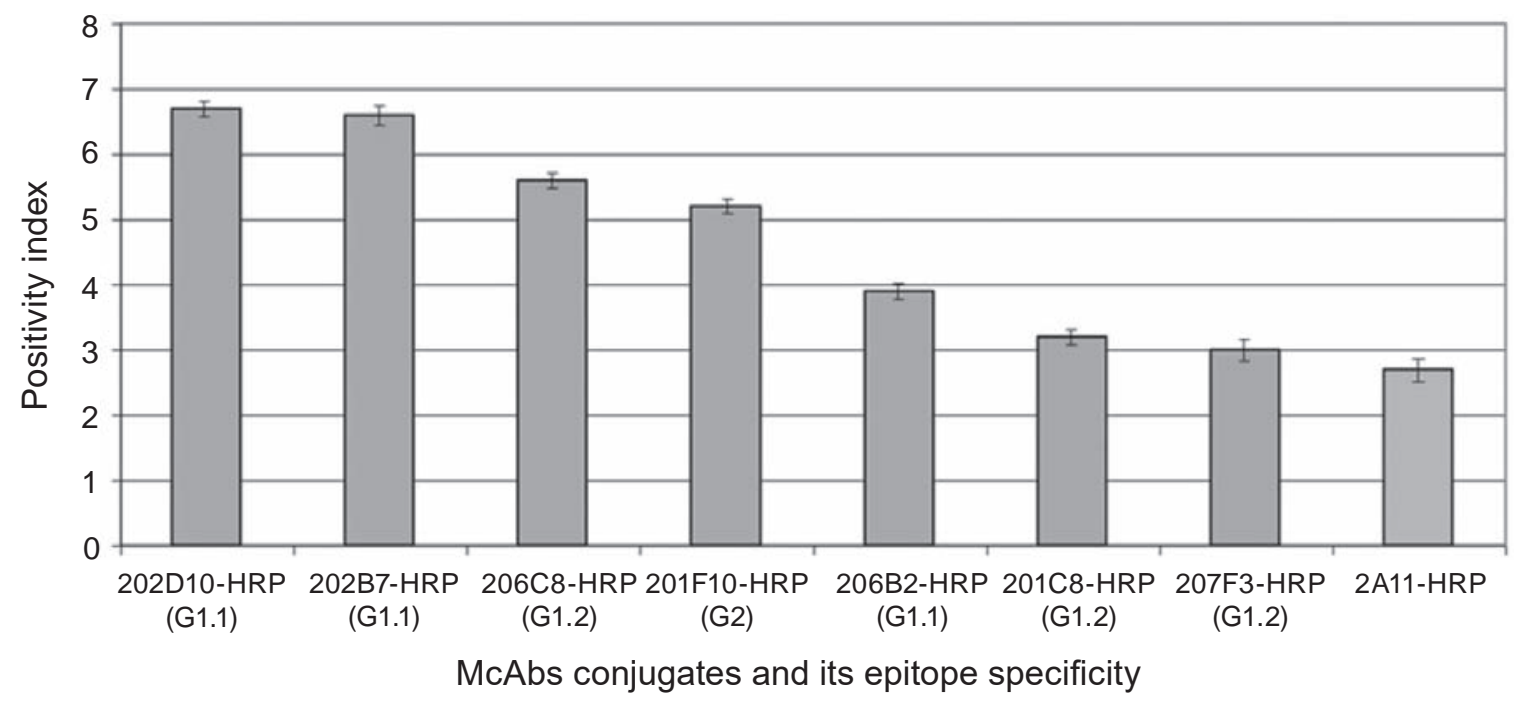

Fig. 3. Results of the primary characterization of McAbs to human IgG in the ELISA to detect IgG antibodies to Pgp3 (PI calculation was based on the results of three replies testing of 8 negative and 8 positive sera for specific anti-MOMP Ig $G$ antibodies; $P<0.05$ )

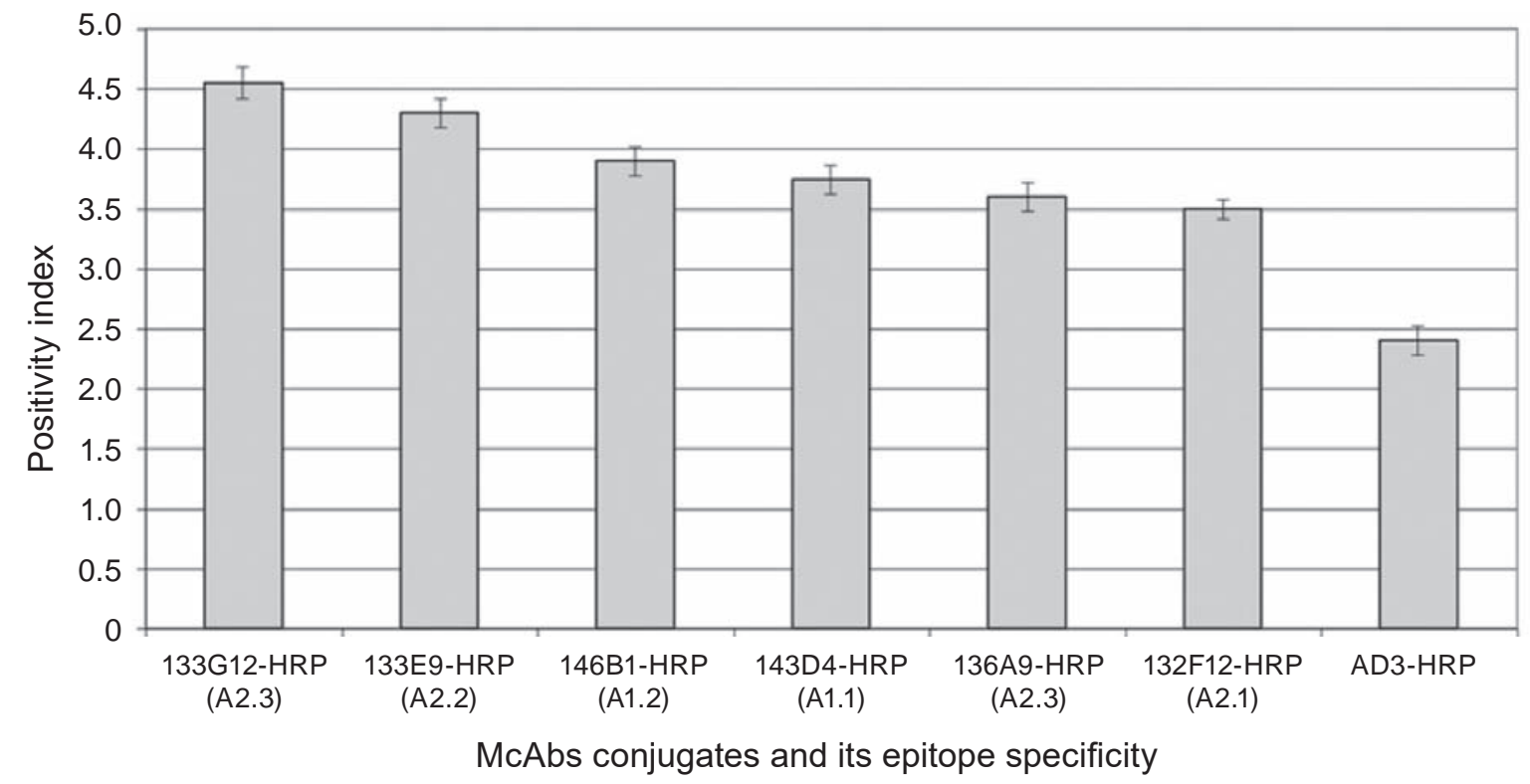

Fig. 4. Results of the primary characterization of McAbs to human IgA in the ELISA to detect IgA antibodies to Pgp3 (PI calculation was based on the results of three replies testing of 8 negative and 8 positive sera for specific anti-MOMP IgA antibodies; $P<0.05$ )

kit. Firstly, we used the pair of 202D10 and 201F10 McAbs which is directed to the epitopes G1.1 and G2, respectively, belonging to different epitopic regions. It should be noted that the 202D10-HRP conjugate was characterized by the highest level of ELISA signaling among the tested monoconjugates; the 201F10-HRP conjugate showed the mean values of the positivity index, but it prevailed in the conjugate of the commercial McAb 2A11). Secondly, we used the pair of 202D10 and 206C8 McAbs, which were directed to different epitopes of one epitopic region G1.1 and G1.2, respectively. The conjugates of both antibodies showed a high PI based on the primary characteristics of the conjugates of McAbs to human IgG in the ELISA.

Comparative studies of conjugates of various pairs of anti-IgG McAbs (Fig. 5) showed that the highest positivity index is appropriate to a pair of 


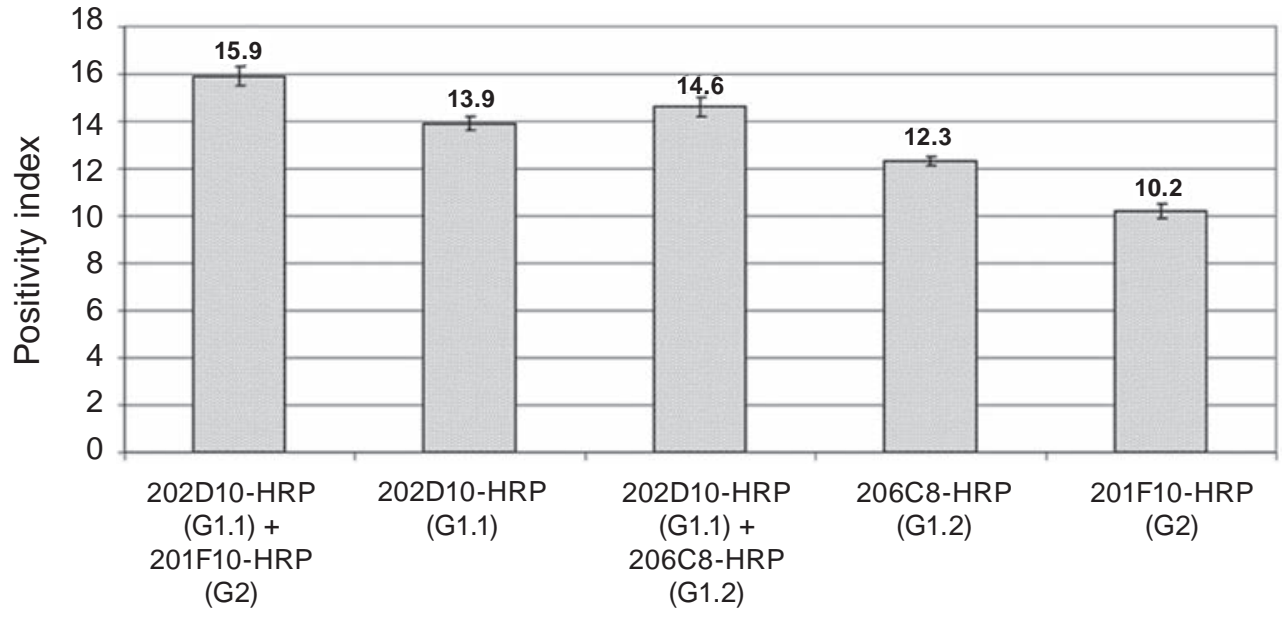

McAbs conjugates and its epitope specificity

Fig. 5. Concomitant use of conjugates of anti-IgG McAbs of different epitopic specificity in ELISA to detect IgG antibodies to MOMP (PI calculation was based on the results of testing of 8 negative and 8 positive sera for specific anti-MOMP IgG antibodies; $P<0.05)$

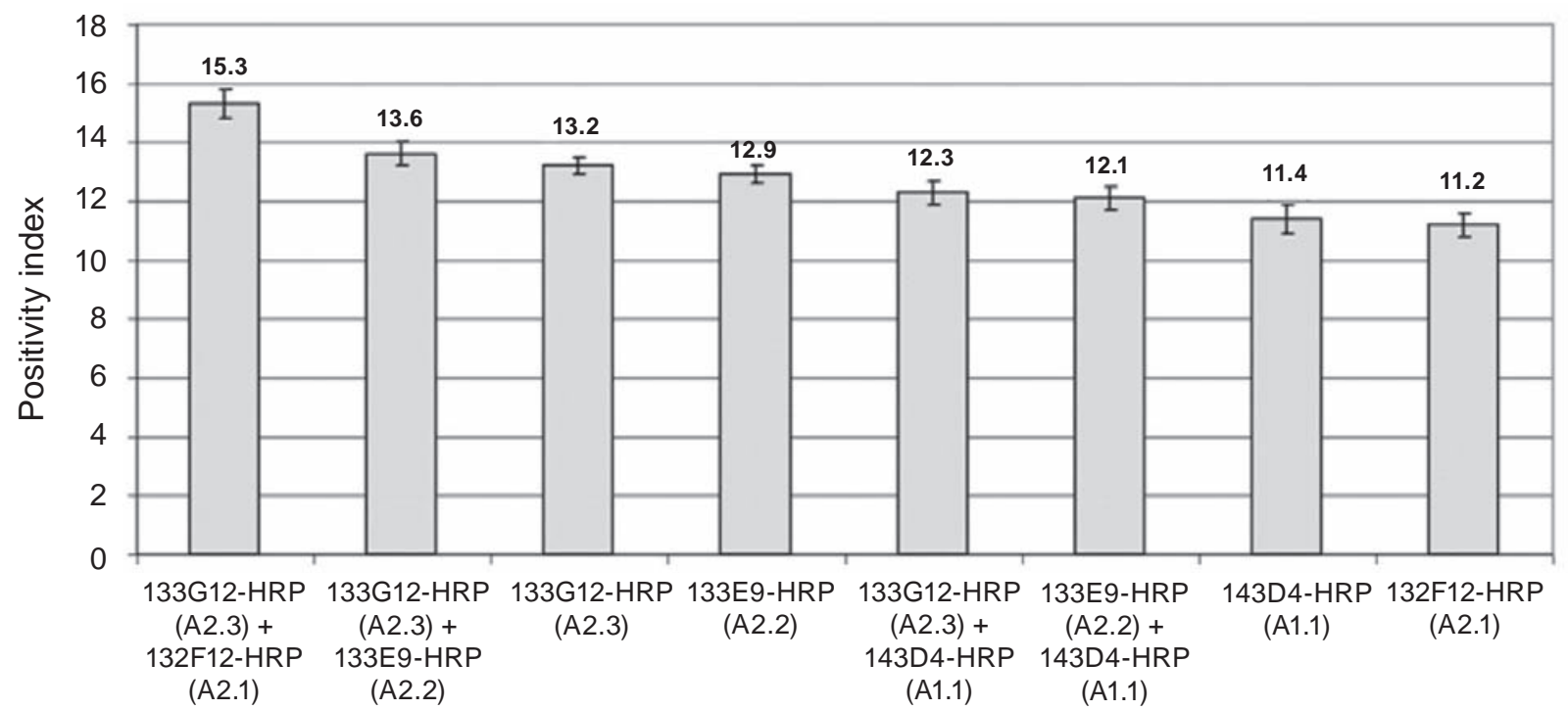

McAbs conjugates and its mixtures (McAbs epitope specificity)

Fig. 6. Concomitant use of conjugates of anti-IgA McAbs of different epitopic specificity in ELISA to detect IgA antibodies to MOMP (PI calculation was based on the results of testing of 8 negative and 8 positive sera for specific anti-MOMP IgA antibodies; $P<0.05)$

conjugates 202D10-HRP + 201F10-HRP: PI of this pair is significantly higher compared to similar results for monoconjugates. At the same time, the combined use of the conjugates of McAbs 202D10 and 206C8, which are directed to the same epitopic region, did not allow us to significantly increase the analysis informativeness. Taking into obtained results, the mixture of conjugates 202D10-HRP +
201F10-HRP is the most promising for use in the further development of high-sensitivity ELISA for the detection of specific IgG antibodies.

To select the pairs of conjugates of antiIgA McAbs for comparative studies of ELISA efficacy, an analysis of the results of the previous characterization of the anti-IgA peroxidase conjugates (Fig. 2) and the complex of biological 
properties of the corresponding McAbs (Table 1) was performed.

For comparative study, the following pairs of McAbs were formed. First, McAbs 133G12 and $132 \mathrm{~F} 12$ were used, which are directed to the epitopes A2.3 and A2.1, respectively, which are the most distant from each other within the epitopic region A2 (Table 1), and are characterized by high values of the PI in ELISA (in case of separate usage) (Fig. 2). Secondly, McAbs 133 G12 and 133E9 were used, which are directed to the epitopes A2.3 and A2.2, respectively, and are also characterized by the best PI results (Fig. 2); thirdly, McAbs 133G12 and 143D4, which are directed to the epitopes A2.3 and A1.1, belonging to different epitopic regions, as well as in the form of monoconjugates, are highly active in the ELISA (Fig. 3); fourthly, the McAbs 133E9 and 143D4, which are directed to the A2.2 and A1.1 epitopes, belonging to different epitopic regions, as well as in the form of monoconjugates, are highly active in the ELISA (Fig. 2).

The performed studies (Fig. 6) showed that the consistent use of the 133G12-HRP + 132F12-HRP conjugates provides the most pronounced increase of the ELISA positivity index - up to 16.2 versus 13.2 for monoconjugate 133G12-HRP and up to 11.2 for monoconjugate 132F12-HRP. The use of other pairs of conjugates increased the value of the ELISA positivity index, but did it less. Based on the obtained results, the most promising way of creating highly sensitive ELISA for the detection of specific IgA antibodies is the mixture of conjugates 133G12-HRP + 132F12-HRP.

In the next step, the stability of the best conjugates of each specificity (202D10-HRP, 201F10HRP, 133G12-HRP, and 132F12-HRP) was tested for long term storage at $37^{\circ} \mathrm{C}$. The obtained results indicate a high stability of the synthesized McAbs conjugates for two months: under the experiment, after 2 months, the conjugates demonstrated from 79 to $85 \%$ of the initial immunochemical activity. These results allow using of these conjugates to develop ELISA test-kits based on it.

Study of diagnostic characteristics of ELISA for detection of $\operatorname{Ig} G$ and $\operatorname{Ig} A$ antibodies specific to MOMP and Pgp 3 Ch. trachomatis. After a series of routine experiments to determine the optimal titers of peroxidase conjugates of McAbs and the concentrations of recombinant proteins for sorption, an assessment of the specificity and sensitivity of the developed ELISA test-kits was performed by the characterized serum panels containing or not containing $\mathrm{IgG} / \mathrm{IgA}$ specific antibodies to Ch. trachomatis (Medical Biological Union, Russia, OCO42-28-313-00 and OCO-42-28-314-00) (Table 3-6). Self developed ELISA test-kits the determination of IgG and IgA antibodies to the MOMP and Pgp3 was conventionally labeled by ELISA-MOMP/Pgp3IgG and ELISA-MOMP/Pgp3-IgA. Relevant studies to detect IgG and IgA antibodies to the urogenital chlamydial pathogen were performed in comparison with commercial diagnostic kits of well-known manufacturers.

Thus, the approach to detect specific antibodies to two antigens of the pathogen of urogenital chlamydia (MOMP and Pgp3), the application of an optimized technique for the synthesis of immunoenzyme conjugates, as well as the use of a mixture of conjugates of monoclonal antibodies directed to different epitopes of immunoglobulin molecules, allowed developing ELISA with significantly better diagnostic characteristics compared to similar commercial test-kits. Thus, as a result of the previous work, a number of biological components (McAbs to human IgG and IgA, Ch. trachomatis recombinant HSP-60) were used to construct ELISA for diagnosis of urogenital chlamydiosis. Other bioreagents (recombinant Ch. trachomatis MOMP and Pgp3) were selected among those presented on the market after preliminary testing of their immunochemical activity.

The logic of further research was to establish the optimal configuration of peroxidase conjugates anti-IgG and anti-IgA McAbs (as monoconjugates or compatible use of conjugates of McAbs of different epitope specificity) for the simultaneous detection of antibodies of a certain class to the MOMP and Pgp3 as the most immunogenic $C h$. trachomatis proteins. The study of immunochemical activity of peroxidase conjugates of McAbs was performed in comparison with conjugates of commercial analogues: anti-IgG McAb 2A11 and anti-IgA McAb AD3. About half of the conjugates from the received McAbs panel were more active compared to the reference antibody conjugates. As in previous studies [20], it was quite justified to use the conjugates of antibodies that interact with different antigenic determinants. When IgG antibodies to MOMP were detected, it was justified 1.14-1.56 times more; when IgA antibodies to MOMP were detected, it was justified 1.16-1.37 times more. The obtained encouraging results were the prerequisite for the development of highly sensitive ELISA for differential serodiagnosis of urogenital chlamydiosis. 
Ta b le 3. Results of the study of the sensitivity and specificity of different ELISA test-kits for detection of IgG antibodies to Ch. trachomatis by using of the characterized serum panel

\begin{tabular}{|c|c|c|c|c|c|c|}
\hline \multirow{3}{*}{$\begin{array}{l}\text { Panel sample } \\
\text { number }\end{array}$} & \multicolumn{6}{|c|}{ ELISA test-kits } \\
\hline & \multicolumn{2}{|c|}{ ELISA-MOMP/Pgp3-IgG } & \multicolumn{2}{|c|}{ Test-kit \#1 (Germany) } & \multicolumn{2}{|c|}{ Test-kit \#2 (Russia) } \\
\hline & OD & PI & OD & PI & OD & PI \\
\hline \multicolumn{7}{|c|}{ Negative serums } \\
\hline 1 & $0.071^{*}$ & 0.38 & 0.075 & 0.19 & 0.088 & 0.31 \\
\hline 2 & 0.076 & 0.41 & 0.099 & 0.25 & 0.089 & 0.32 \\
\hline 3 & 0.098 & 0.52 & 0.192 & 0.49 & 0.147 & 0.53 \\
\hline 4 & 0.144 & 0.77 & 0.291 & 0.75 & 0.091 & 0.33 \\
\hline 5 & 0.095 & 0.51 & 0.088 & 0.23 & 0.183 & 0.65 \\
\hline 6 & 0.116 & 0.62 & 0.095 & 0.24 & 0.201 & 0.72 \\
\hline 7 & 0.065 & 0.35 & 0.077 & 0.20 & 0.147 & 0.53 \\
\hline 8 & 0.057 & 0.31 & 0.155 & 0.40 & 0.093 & 0.33 \\
\hline 9 & 0.062 & 0.33 & 0.069 & 0.18 & 0.136 & 0.49 \\
\hline 10 & 0.129 & 0.69 & 0.229 & 0.59 & 0.116 & 0.41 \\
\hline 11 & 0.088 & 0.47 & 0.166 & 0.43 & 0.098 & 0.35 \\
\hline 12 & 0.085 & 0.46 & 0.159 & 0.41 & 0.085 & 0.30 \\
\hline 13 & 0.118 & 0.63 & 0.122 & 0.31 & 0.198 & 0.71 \\
\hline 14 & 0.157 & 0.84 & 0.229 & 0.59 & 0.131 & 0.47 \\
\hline 15 & 0.047 & 0.25 & 0.147 & 0.38 & 0.074 & 0.26 \\
\hline 16 & 0.065 & 0.35 & 0.189 & 0.48 & 0.061 & 0.22 \\
\hline 17 & 0.041 & 0.22 & 0.199 & 0.51 & 0.041 & 0.15 \\
\hline 18 & 0.032 & 0.17 & 0.087 & 0.22 & 0.055 & 0.20 \\
\hline 19 & 0.087 & 0.47 & 0.298 & 0.76 & 0.036 & 0.13 \\
\hline 20 & 0.083 & 0.44 & 0.110 & 0.28 & 0.109 & 0.39 \\
\hline \multicolumn{7}{|c|}{ Positive serums } \\
\hline 21 & 2.089 & 11.19 & 0.589 & 1.51 & 2.066 & 7.38 \\
\hline 22 & 1.469 & 7.87 & 0.988 & 2.53 & 1.801 & 6.43 \\
\hline 23 & 2.606 & 13.96 & 0.722 & 1.85 & 2.215 & 7.91 \\
\hline 24 & 0.089 & 0.48 & 0.698 & 1.79 & 0.752 & 2.69 \\
\hline 25 & 1.316 & 7.05 & 0.628 & 1.61 & 1.211 & 4.33 \\
\hline 26 & 2.440 & 13.07 & 2.681 & 6.87 & 2.451 & 8.75 \\
\hline 27 & 1.997 & 10.69 & 0.855 & 2.19 & 1.901 & 6.79 \\
\hline 28 & 1.099 & 5.89 & 0.455 & 1.17 & 1.028 & 3.67 \\
\hline 29 & 0.988 & 5.29 & 0.501 & 1.28 & 0.877 & 3.13 \\
\hline 30 & 2.447 & 13.10 & 1.113 & 2.85 & 2.114 & 7.55 \\
\hline 31 & 1.086 & 5.82 & 0.895 & 2.29 & 0.704 & 2.51 \\
\hline 32 & 2.458 & 13.16 & 0.457 & 1.17 & 2.145 & 7.66 \\
\hline 33 & 1.781 & 9.54 & 0.366 & 0.94 & 1.366 & 4.88 \\
\hline 34 & 2.101 & 11.25 & 1.455 & 3.73 & 1.904 & 6.80 \\
\hline 35 & 2.411 & 12.91 & 0.418 & 1.07 & 1.814 & 6.48 \\
\hline 36 & 1.522 & 8.15 & 1.101 & 2.82 & 0.699 & 2.50 \\
\hline
\end{tabular}

Note.* The arithmetic average values of OD for each sample in three replies are presented; $P<0.05$. 
Table 4. Comparative characteristics of different ELISA test-kits for detection of IgG antibodies to Ch. trachomatis

\begin{tabular}{l|c|c|c}
\hline \multirow{2}{*}{ Analysis characteristics } & \multicolumn{3}{|c}{ ELISA test-kits } \\
\cline { 2 - 4 } & $\begin{array}{c}\text { Test-kit \#1 } \\
\text { (Germany) }\end{array}$ & Test-kit \#2 (Russia) & $\begin{array}{c}\text { ELISA-MOMP/ } \\
\text { Pgp3-IgG }\end{array}$ \\
\hline The mean value of OD of negative serums & 0.154 & 0.109 & 0.086 \\
The mean value of OD of positive serums & 0.870 & 1.566 & 1.744 \\
$\begin{array}{l}\text { Cut-off } \\
\text { The ratio of mean values of OD }\end{array}$ & 0.364 & 0.254 & 0.187 \\
of positive and negative serums & 5.66 & 14.37 & 20.32 \\
\hline
\end{tabular}

Table 6. Comparative characteristics of different ELISA test-kits for detection of IgA antibodies to Ch. trachomatis

\begin{tabular}{l|c|c|c}
\hline \multirow{2}{*}{ Analysis characteristics } & \multicolumn{3}{|c}{ ELISA test-kits } \\
\cline { 2 - 4 } & $\begin{array}{c}\text { Test-kit \#3 } \\
\text { (Germany) }\end{array}$ & Test-kit \#4 (Russia) & $\begin{array}{c}\text { ELISA-MOMP/ } \\
\text { Pgp3-IgA }\end{array}$ \\
\hline The mean value of OD of negative serums & 0.155 & 0.114 & 0.090 \\
The mean value of OD of positive serums & 0.644 & 0.972 & 1.044 \\
$\begin{array}{l}\text { Cut-off } \\
\text { The ratio of mean values of OD }\end{array}$ & 0.333 & 0.346 & 0.263 \\
of positive and negative serums & 4.15 & 8.55 & 11.59 \\
\hline
\end{tabular}

The designed ELISA needed to be evaluated, at least for the most important qualitative indicators sensitivity and specificity. ELISA for detecting IgG/ IgA antibodies to MOMP and Pgp3 of Ch. trachomatis could be evaluated using appropriately described serum panels presented on the market, for example, OCO-42-28-313-00 and OCO-42-28-314-00. Comparative studies of the developed ELISA for the de- tection of IgG and IgA antibodies to the MOMP and Pgp3 of Ch. trachomatis showed their prominent advantage over the commercial analogues, which more clearly demonstrates the difference in the ratio of average values of optical density of positive and negative samples of the described panel of sera: this indicator for commercial kits was less in 1.36-3.59 times. 
Ta b le 5. Results of the study of the sensitivity and specificity of different ELISA test-kits for detection of IgA antibodies to Ch. trachomatis by using of the characterized serum panel

\begin{tabular}{|c|c|c|c|c|c|c|}
\hline \multirow{3}{*}{$\begin{array}{c}\text { Panel sample } \\
\text { number }\end{array}$} & \multicolumn{6}{|c|}{ ELISA test-kits } \\
\hline & \multicolumn{2}{|c|}{ ELISA-MOMP/Pgp3-IgA } & \multicolumn{2}{|c|}{ Test-kit \#3 (Germany) } & \multicolumn{2}{|c|}{ Test-kit \#4 (Russia) } \\
\hline & OD & PI & OD & $\mathrm{OD}^{*}$ & PI & OD \\
\hline \multicolumn{7}{|c|}{ Negative serums } \\
\hline 1 & $0.121^{*}$ & 0.46 & 0.142 & 0.39 & 0.118 & 0.32 \\
\hline 2 & 0.107 & 0.41 & 0.102 & 0.28 & 0.137 & 0.37 \\
\hline 3 & 0.123 & 0.47 & 0.082 & 0.23 & 0.188 & 0.51 \\
\hline 4 & 0.260 & 0.99 & 0.077 & 0.21 & 0.295 & 0.80 \\
\hline 5 & 0.047 & 0.18 & 0.211 & 0.59 & 0.055 & 0.15 \\
\hline 6 & 0.038 & 0.14 & 0.255 & 0.71 & 0.039 & 0.11 \\
\hline 7 & 0.104 & 0.39 & 0.150 & 0.42 & 0.166 & 0.45 \\
\hline 8 & 0.084 & 0.32 & 0.207 & 0.58 & 0.111 & 0.30 \\
\hline 9 & 0.069 & 0.26 & 0.206 & 0.57 & 0.078 & 0.21 \\
\hline 10 & 0.039 & 0.15 & 0.152 & 0.42 & 0.029 & 0.08 \\
\hline 11 & 0.142 & 0.54 & 0.159 & 0.44 & 0.104 & 0.28 \\
\hline 12 & 0.032 & 0.12 & 0.241 & 0.67 & 0.038 & 0.10 \\
\hline 13 & 0.138 & 0.52 & 0.091 & 0.25 & 0.266 & 0.72 \\
\hline 14 & 0.032 & 0.12 & 0.129 & 0.36 & 0.030 & 0.08 \\
\hline 15 & 0.120 & 0.46 & 0.214 & 0.59 & 0.153 & 0.41 \\
\hline 16 & 0.041 & 0.16 & 0.089 & 0.25 & 0.085 & 0.23 \\
\hline 17 & 0.039 & 0.15 & 0.086 & 0.24 & 0.047 & 0.13 \\
\hline 18 & 0.086 & 0.33 & 0.200 & 0.56 & 0.108 & 0.29 \\
\hline \multicolumn{7}{|c|}{ Positive serums } \\
\hline 19 & 0.788 & 2.99 & 0.359 & 1.00 & 0.701 & 1.89 \\
\hline 20 & 0.719 & 2.73 & 0.712 & 1.98 & 0.613 & 1.66 \\
\hline 21 & 0.658 & 2.50 & 0.863 & 2.40 & 0.544 & 1.47 \\
\hline 22 & 0.322 & 1.22 & 0.462 & 1.28 & 0.325 & 0.88 \\
\hline 23 & 0.506 & 1.92 & 0.401 & 1.11 & 0.499 & 1.35 \\
\hline 24 & 1.128 & 4.28 & 0.377 & 1.05 & 0.984 & 2.66 \\
\hline 25 & 0.747 & 2.84 & 0.341 & 0.95 & 0.744 & 2.01 \\
\hline 26 & 2.020 & 7.67 & 1.122 & 3.12 & 1.988 & 5.37 \\
\hline 27 & 1.439 & 5.46 & 0.370 & 1.03 & 1.366 & 3.69 \\
\hline 28 & 1.988 & 7.55 & 1.874 & 5.21 & 1.811 & 4.89 \\
\hline 29 & 0.411 & 1.56 & 0.419 & 1.16 & 0.390 & 1.05 \\
\hline 30 & 1.805 & 6.85 & 0.425 & 1.18 & 1.700 & 4.59 \\
\hline
\end{tabular}

Note.* The arithmetic average values of OD for each sample in three replies are presented; $P<0.05$. 


\section{РОЗРОБКА ТА ХАРАКТЕРИСТИКА ВИСОКОІНФОРМАТИВНОГО ІМУНОЕНЗИМНОГО АНАЛІЗУ ДЛЯ ВИЯВЛЕННЯ IgG ТА IgA АНТИТІЛ ДО Chlamydia trachomatis}

\author{
О. Ю. Галкін ${ }^{1}$ Ю. В. Гориунов ${ }^{1}$ \\ О. Б. Бесараб, О. М. Іванова ${ }^{2}$
}
${ }^{1}$ Національний технічний університет України «Київський політехнічний інститут імені Ігоря Сікорського»; e-mail: alexfbt@gmail.com;
${ }^{2}$ ТОВ «Хема», Київ

Метою роботи була розробка високоінформативного імуноензимного аналізу (IEA) для виявлення IgG та IgA-антитіл до Chlamydia trachomatis, а також порівняльна характеристика розробленого аналізу із застосуванням стандартизованих контрольних матеріалів. Дослідження проводилось із використанням: моноклональних антитіл (МкАт) до $\operatorname{IgA}$ та IgG людини; рекомбінантних протеїнів Ch. trachomatis - Pgp3; основного протеїну зовнішньої мембрани (МОМР); двох панелей охарактеризованих сироваток та чотирьох референтних IEA-наборів. Імунохімічну активність пероксидазних кон'югатів МкАт порівнювали із комерційними аналогами - анти-IgG МкАт 2A11 та анти-IgA МкАт AD3. Показано, що близько половини кон'югатів із одержаної панелі МкАт були активнішими порівняно із кон'югатами референтних антитіл. Цілком виправданим виявилося сумісне використання кон'югатів антитіл, що взаємодіють із різними антигенними детермінантами: у разі виявлення IgGантитіл до МОМР - у 1,14-1,56 раза; за виявлення IgA-антитіл до МOMP - у 1,16-1,37 раза. Сконструйовані IEA оцінювали за допомогою відповідних охарактеризованих панелей сироваток ОСО-42-28-313-00 та ОСО-42-28-314-00. Порівняльні дослідження розроблених IЕA для виявлення IgG- та IgA-антитіл до МOMP та Pgp3 Ch. trachomatis показали помітну їх перевагу над комерційними наборами, що яскраво демонструє розбіжність у співвідношенні середніх значень оптичної густини позитивних та негативних зразків охарактеризованої панелі сироваток: цей показник для комерційних наборів був менше в 1,36-3,59 раза.
К л ю ч о в і с л о в а: імуноензимний аналіз, Ch. trachomatis, основний протеїн зовнішньої мембрани, Pgp3, чутливість, специфічність.

РАЗРАБОТКА И ХАРАКТЕРИСТИКА
ВЫСОКОИНФОРМАТИВНОГО
ИММУНОЭНЗИМНОГО АНАЛИЗА
ДЛЯ ВЫЯВЛЕНИЯ IgG И IgА
АНТИТЕЛ К Chlamydia trachomatis

А. Ю. Галкин ${ }^{1}$ Ю. В. Горшунов ${ }^{1}$ А. Б. Бесараб ${ }^{1}$ О. М. Иванова ${ }^{2}$
${ }^{1}$ Национальный технический университет Украины «Киевский политехнический институт имени Игоря Сикорского»; e-mail: alexfbt@gmail.com; ${ }^{2} \mathrm{OOO}$ «Хема», Киев

Целью работы была разработка высокоинформативного иммуноэнзимного анализа (ИЭА) для выявления IgG и IgA-антител к Chlamydia trachomatis, а также сравнительная характеристика разработанного анализа с использованием стандартизированных контрольных материалов. Исследование проводили с применением моноклональных антител (МкАт) к IgA и IgG человека; рекомбинантных протеинов Ch. trachomatis Pgp3; основного протеина наружной мембраны (МОМР); двух панелей охарактеризованных сывороток и четырех референтных ИЭА-наборов. Иммунохимическую активность пероксидазных конъюгатов МкАт сравнивали с коммерческими аналогами - анти- $\operatorname{IgG}$ МкАт 2A11 и антиIgA МкAт AD3. Показано, что около половины конъюгатов МкАт были более активными по сравнению с конъюгатами референтных антител. Вполне оправданным оказалось совместное использование конъюгатов антител, взаимодействующих с различными антигенными детерминантами: при обнаружении IgG-антител к MOMP - в 1,14-1,56 раза; при выявлении IgAантител к МОМР - в 1,16-1,37 раза. Сконструированы ИЭА были оценены с помощью соответствующих охарактеризованных панелей сывороток ОСО-42-28-313-00 и ОСО-42-28314-00. Сравнительные исследования разработанных ИЭА для выявления IgG- и IgA-антител к MOMP и Pgp3 Ch. trachomatis показали заметное их преимущество перед коммерческими наборами, что ярко демонстрируется различием 
в соотношении средних значений оптической плотности положительных и отрицательных образцов охарактеризованной панели сывороток: данный показатель для коммерческих наборов был меньше в 1,36-3,59 раза.

К л ю ч е в ы е с ло в а: иммуноэнзимный анализ, Ch. trachomatis, основной протеин внешней мембраны, Pgp3, чувствительность, специфичность.

\section{References}

1. Chinov GP. Revalence and clinical characteristic of chlamydia trachomatis and trichomonas vaginalis - the most widespread sexual transmissed infections. Ukr J Dermatol Venerol Cosmetol. 2005; (1): 74-81. (In Ukrainian).

2. Mavrov GI, Shcherbakova IV, Chinov GP. The treatment of complicated chamydial infection with azithromycin (Sumamed) using in combination with pathogenetic therapy. $U k r J$ Dermatol Venerol Cosmetol. 2010; (3): 123-127. (In Russian).

3. Isakov VA, Kulyashova LB, Berezina LA, Svarval AV. Laboratory diagnostics of urogenital chlamydiosis. Part 2. Methods of diagnosis of chlamydial infection: an analytical review (see the beginning No 1, 2012). Terra Medica. Labor. Diagn. 2013; 1: 13-21. (In Russian).

4. Rahmatulina MR, Popov DV, Plahova KI. Current concepts of the epidemiology, clinical picture, diagnostics and therapy of non-complicated and complicated forms of the urogenital chlamydia infection in men. Vestnik Dermatol Venerol. 2012; (6): 35-41.

5. Ganda IS, Zhong Q, Hali M, Albuquerque RLC, Padilha FF, da Rocha SRP, Whittum-Hudson JA. Dendrimer-conjugated peptide vaccine enhances clearance of Chlamydia trachomatis genital infection. Int J Pharm. 2017; 527(1-2): 79-91.

6. Molina DM, Pal S, Kayala MA, Teng A, Kim PJ, Baldi P, Felgner PL, Liang X, de la Maza LM. Identification of immunodominant antigens of Chlamydia trachomatis using proteome microarrays. Vaccine. 2010; 28(17): 3014-3024.

7. Galkin A, Dugan A, Solovjova V, Bondarenko L. New monoclonal antibodies to human IgA: obtaining and study of biological properties. $\mathrm{Br}$ Biotechnol J. 2015. 8(4): 1-9.
8. Tijssen P. Practice and theory of enzyme immunoassays. Lab Techiques Biochem Mol Biol. 1985; 15: 548 p.

9. Galkin OYu, Savchenko AA, Nikitina KI, Dugan OM. Obtaining and study of properties of new monoclonal antibodies against human IgE. Ukr Biokhim Zhurn. 2013; 85(5): 81-87. (In Ukrainian).

10. Winstanley CE, Ramsey KH, Marsh P, Clarke IN. Development and evaluation of an enzymelinked immunosorbent assay for the detection of antibodies to a common urogenital derivative of Chlamydia trachomatis plasmid-encoded PGP3. J Immunol Methods. 2017; 445: 23-30.

11. Donati M, Laroucau K, Storni E, Mazzeo C, Magnino S, Di Francesco A, Baldelli R, Ceglie L, Renzi M, Cevenini R. Serological response to pgp3 protein in animal and human chlamydial infections. Vet Microbiol. 2009; 135(1-2): 181-185.

12. Murdin AD, Su H, Manning DS, Klein MH, Parnell MJ, Caldwell HD. A poliovirus hybrid expressing a neutralization epitope from the major outer membrane protein of Chlamydia trachomatis is highly immunogenic. Infect Immun. 1993; 61(10): 4406-4414.

13. Pacchiarotti A, Sbracia M, Mohamed MA, Frega A, Pacchiarotti A, Espinola SM, Aragona C. Autoimmune response to Chlamydia trachomatis infection and in vitro fertilization outcome. Fertil Steril. 2009; 91(3): 946-948.

14. Cortiñas P, Muñoz MG, Loureiro CL, Pujol FH. Follicular fluid antibodies to Chlamydia trachomatis and human heat shock protein-60 kDa and infertility in women. Arch Med Res. 2004; 35(2): 121-125.

15. Obrjadina AP, Kopnina EO, Golubeva IF. Diagnosis of chlamydia. Information materials. N. Novgorod: Diagnostic systems, 2008. 28 p.

16. Kulyashova LB, Berezina LA, Ivanova MB. Experience in the diagnosis of chlamydial infection. Clin Lab Diagnostics. 2000; (10): 39.

17. Manzenyuk IM, Vorobyova MS, Nikityunk NM, Fedosov SA, Losev MV. Evaluation of the first russian enzyme immunoassay recombinant test system Chlamy-IgA-DC-Tr for detecting IgA to Chlamydia trachomatis. Clin Lab Diagnostics. 2002; (6): 40-41. 
18. Chevaliez S, Pawlotsky JM. Hepatitis C virus serologic and virologic tests and clinical diagnosis of HCV-related liver disease. Int $J$ Med Sci. 2006; 3(2): 35-40.

19. Young H, Moyes A, Seagar L, McMillan A. Novel recombinant-antigen enzyme immunoassay for serological diagnosis of syphilis. J Clin Microbiol. 1998; 36(4): 913-917.
20. Galkin OYu, Besarab AB, Lutsenko TN. Characteristics of enzyme-linked immunosorbent assay for detection of IgG antibodies specific to Chlamydia trachomatis heat shock protein (HSP-60). Ukr Biochem J. 2017; 89(1): 22-30.

Received 09.01.2018 